\title{
Research of the chemical composition of Artemisia tschernieviana Bess. by gas chromatography method with mass detection
}

\author{
O. I. Panasenko@E,F, V. I. MozulA,B,E, O. M. Denysenko ${ }^{A, B, E}$, I. I. Aksonova@ ${ }^{\circledR C, D}$, V. V. Holovkin ${ }^{B, E}$
}

Zaporizhzhia State Medical University, Ukraine

A - research concept and design; B - collection and/or assembly of data; C - data analysis and interpretation; D - writing the article;

$\mathrm{E}$ - critical revision of the article; $\mathrm{F}$ - final approval of the article

The aim of the work was to study chromato-mass spectroscopic of Artemisia tschernieviana Bess. grass and to establish possible prospects for the use of this plant in medical practice.

Materials and methods. Artemisia tschernieviana Bess. grass was chosen as the object of research. Raw materials were collected in July 2021 in the flowering phase (Zaporizhzhia). The tincture was obtained by maceration and the raw material was extracted with methyl alcohol at room temperature for 10 days according to the method of making tinctures. The study of the chemical composition of Artemisia tschernieviana Bess. Grass was carried out using gas chromatograph Agilent 7890B GC System (Agilent, Santa Clara, CA, USA) with mass spectrometric detector Agilent 5977 BGC/MSD (Agilent, Santa Clara, CA, USA) and chromatographic column DB-5ms $(30 \mathrm{~m} \times 250 \mu \mathrm{m} \times 0.25 \mu \mathrm{m})$

Results. During the study it was found that the composition of Artemisia tschernieviana Bess. grass includes 21 compounds (2 in the isomeric state). $\beta$-myrcene (17.22 \%), sabinene (14.54 \%), 2-(4a,8-dimethyl-7-oxo-1,2,3,4,4a,7-hexahydronaphthalen-2-yl) propionic acid (11.57\%), 2-dodecen-1-yl-succinic anhydride (10.84\%) and chamazulene (9.02\%) accounted for the largest percentage.

According to the literature review, myrcene has antibacterial, anesthetic and analgesic effects. Sabinene is characterized by antibacterial action. 2-(4a,8-dimethyl-7-oxo-1,2,3,4,4a,7-hexahydronaphthalen-2-yl)-propionic acid is a fatty acid with possible antibacterial and anti-inflammatory activity. 2-dodecen-1-yl-succinic anhydride is used to produce anhydride-modified form of insulin that can be used in the treatment of diabetes. Hamazulen has anti-inflammatory activity.

Conclusions. In view of all the above, we can conclude that Artemisia tschernieviana Bess. grass can be recommended for further research as a source of potential anti-inflammatory and antibacterial agents.

Key words: Artemisia tschernieviana, GS-MS, component composition, quantitative content, anti-inflammatory effect, antidiabetic effect, antibacterial effect.

Current issues in pharmacy and medicine: science and practice 2021; 14 (3), 282-286

\section{Дослідження хімічного складу Artemisia tschernieviana Bess. методом газової хроматографії з мас-детекцією}

\section{О. І. Панасенко, В. І. Мозуль, О. М. Денисенко, І. І. Аксьонова, В. В. Головкін}

Мета роботи - визначення хімічного складу полину Черняєва трави, встановлення перспективності ії дослідження як потенційного джерела лікарських засобів з антибактеріальною та протизапальною діями.

Матеріали та методи. Об'єкт дослідження - полину Черняєва трава. Сировину зібрали в липні 2021 року у фазу цвітіння (м. 3апоріжжя). Настойку одержали методом мацерації, сировину екстрагували метиловим спиртом за кімнатної температури протягом 10 днів відповідно до методики виготовлення настойок. Хімічний склад настойки вивчали за допомогою газового хроматографа Agilent 7890B GC System (Agilent, Санта-Клара, Каліфорнія, США) з мас-спектрометричним детектором Agilent 5977 BGC/MSD (Agilent, Santa Clara, CA, США) та хроматографічної колонки DB-5ms (30 м × 250 мкм × 0,25 мкм).

Результати. У результаті дослідження встановили, що полину Черняєва трава містить 21 сполуку (2 - в ізомерному стані). Найбільший відсоток становили $\beta$-мірцен (17,22 \%), сабінен (14,54 \%), 2-(4a,8-диметил-7-оксо-1,2,3,4,4а,7-гексагідронафтален-2-іл)-пропіонова кислота (11,57 \%), 2-додецен-1-іл-сукциновий ангідрид (10,84\%), хамазулен $(9,02 \%)$. Відомо, що мірцену притаманна антибактеріальна, знеболювальна та аналгетична дії. Для сабінену характерна антибактеріальна дія. 2-(4а,8-диметил-7-оксо-1,2,3,4,4а,7-гексагідронафттален-2-іл)-пропіонова кислота - жирна кислота з можливою антибактеріальною та протизапальною активністю. 2-додецен-1-іл-сукциновий ангідрид використовують для отримання ангідрид-модифрікованої форми інсуліну, який можна застосовувати в терапії цукрового діабету. Хамазулен характеризується протизапальною дією.

ARTICLE

INFO

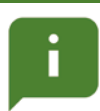

http:l/pharmed.

article/

view/242650
UDC 615.322:582.998.16-119.21.074:543.544.3

DOI: $10.14739 / 2409-2932.2021 .3 .242650$

Current issues in pharmacy and medicine: science and practice 2021; 14 (3), 282-286

Key words: Artemisia tschernieviana, GS-MS, component composition, quantitative content, anti-inflammatory effect, antidiabetic effect, antibacterial effect.

*E-mail: bruttik2@gmail.com

Received: 18.08.2021 // Revised: 13.09.2021 // Accepted: 22.09.2021 
Висновки. Полину Черняєва траву можна рекомендувати для наступних досліджень як потенційне джерело протизапальних та антибактеріальних засобів.

Ключові слова: Artemisia tschernieviana, GS-MS, компонентний склад, кількісний вміст, протизапальний ефект, протидіабетичний ефект, антибактеріальний ефект.

Актуальні питання фармацевтичної і медичної науки та практики. 2021. Т. 14, № 3(37). С. 282-286

Исследование химического состава Artemisia tschernieviana Bess. методом газовой хроматографиии с масс-детекцией

\section{А. И. Панасенко, В. И. Мозуль, О. Н. Денисенко, И. И. Аксёнова, В. В. Головкин}

Цель работы - определение химического состава полыни Черняева травы, установление перспективности её исследования как потенциального источника лекарственных средств с антибактериальным и противовоспалительным действиями.

Материалы и методы. Объект исследования - полыни Черняева трава. Сырьё собрано в июле 2021 года в фразу цветения (г. Запорожье). Настойку получали методом мацерации, сырье экстрагировали метиловым спиртом при комнатной температуре в течение 10 дней в соответствии с методикой изготовления настоек. Химический состав настойки изучили с помощью газового хроматографа Agilent 7890B GC System (Agilent, Санта-Клара, Калифорния, США) с масс-спектрометрическим детектором Agilent 5977 BGC/MSD (Agilent, Santa Clara, CA, США) и хроматографической колонки DB-5ms (30 м × 250 мкм × 0,25 мкм).

Результаты. В ходе исследования установлено, что полыни Черняева трава содержит 21 соединение (2-в изомерном состоянии). Наибольший процент составили $\beta$-мирцен (17,22 \%), сабинен (14,54 \%), 2-(4а,8-диметил-7-оксо-1,2,3,4,4а,7-гексагидронафтален-2-ил)-пропионовая кислота (11,57 \%), 2-додецен-1-ил-сукциновый ангидрид (10,84 \%) и хамазулен $(9,02 \%)$.

Известно, что мирцен характеризуется антибактериальным, анестезирующим и анальгезирующим действиями. Сабинен проявляет антибактериальное действие. 2-(4а,8-диметил-7-оксо-1,2,3,4,4а,7-гексагидронафтален-2-ил)-пропионовая кислота - жирная кислота с вероятным антибактериальным и противовоспалительным эффектами. 2-додецен-1-ил-сукциновый ангидрид используют для получения ангидрид-модифицированной формы инсулина, который можно применять в терапии сахарного диабета. Хамазулен обладает противовоспалительным действием.

Выводы. Полыни Черняева трава может быть рекомендована для дальнейших исследований как источник потенциальных противовоспалительных и антибактериальных средств.

Ключевые слова: Artemisia tschernieviana, GS-MS, компонентный состав, количественное содержание, противовоспалительный эффект, противодиабетический эффект, антибактериальный эффект.

Актуальные вопросы фрармацевтической и медицинской науки и практики. 2021. Т. 14, № 3(37). С. 282-286

The genus Artemisia is one of the largest and most common plants in the family Asteraceae [1,2]. It has more than 400 species that grow mainly throughout the northern hemisphere, in the temperate zone of Eurasia, in North and South Africa, North America [3]. There are 22 species on the territory of Ukraine. Representatives of the genus are mainly annual, biennial, and perennial herbaceous plants or shrubs, usually aromatic [4,5].

Many species of Artemisia are the subject of research by scientists from around the world. In particular, this is due to the complex chemical composition of these plants and the presence of a wide range of biological effects [6,7]. Thus, several scientists confirm the presence of cytotoxic and antitumor effects in some species of the genus [8]. For example, German scientists have confirmed the high effectiveness of Artemisia annua L. extract against breast cancer [9]. Pakistani researchers describe the presence of antitumor, cytotoxic, antimalarial, and antidiabetic effects in Artemisia maritima $L$. [10]. A wide range of biological action is characteristic of Artemisia absinthium L. Thus, there are data on its use as an antioxidant, antifungal, antimicrobial, anthelmintic, antiulcer, hepatoprotective, and analgesic [11]. A similar effect is characteristic of Artemisia nilagirica L. [12].

However, the further literature review revealed a lack of information on the chemical composition and use of Artemisia tschernieviana Bess. This confirms the feasibility and relevance of research in this area.
Aim

The aim of the work was to study chromato-mass spectroscopic of Artemisia tschernieviana Bess. grass and to establish possible prospects for the use of this plant in medical practice.

\section{Materials and methods}

Plant materials. The object of the study was Artemisia tschernieviana Bess. grass. Raw materials were collected in July 2021 in the flowering phase (Zaporizhzhia, Ukraine).

Extraction. The tincture was obtained by maceration, and the raw material was extracted with methyl alcohol at room temperature for 10 days according to the method of making tinctures. $0.1 \mathrm{ml}$ of the extract was placed in a $1 \mathrm{ml}$ micro flask and made up to $0.5 \mathrm{ml}$ with methanol [13].

Equipment. Qualitative and quantitative determination of active compounds was carried out at the Department of Natural Sciences for Foreign Students and Toxicological Chemistry (Head of the Department - Dr. hab., Professor O. I. Panasenko).

The completeness of the reactions and the individuality of the resulting compounds were controlled by the gas chromatograph Agilent 7890B with a 5977B mass spectrometry detector. The column is DB-5ms $30 \mathrm{~m} \times 250 \mu \mathrm{m} \times 0.25 \mu \mathrm{m}$ with length. The gas-carrier speed (helium) is $1.6 \mathrm{ml} / \mathrm{min}$. Injection volume $-0.5 \mu$ l. Separation of the flow is $1: 50$. 
Table 1. Qualitative and quantitative content of biologically active compounds of Artemisia tschernieviana Bess. grass

\begin{tabular}{|c|c|c|c|}
\hline Compound Label & RT & Area Sum $\%$ & DB Formula \\
\hline Cpd 1: 2,2-Dimethoxybutane & 1.971 & 1.86 & $\mathrm{C}_{6} \mathrm{H}_{14} \mathrm{O}_{2}$ \\
\hline Cpd 2: Bicyclo[3.1.0]hexane, 4-methylene-1-(1-methylethyl)- & 4.117 & 14.54 & $\mathrm{C}_{10} \mathrm{H}_{16}$ \\
\hline Cpd 3: .beta.-Myrcene & 4.267 & 17.22 & $\mathrm{C}_{10} \mathrm{H}_{16}$ \\
\hline Cpd 4: Linalool & 5.761 & 2.46 & $\mathrm{C}_{10} \mathrm{H}_{18} \mathrm{O}$ \\
\hline Cpd 5: Caryophyllene & 10.285 & 1.71 & $\mathrm{C}_{15} \mathrm{H}_{24}$ \\
\hline Cpd 6: Galacto-heptulose & 10.426 & 1.16 & $\mathrm{C}_{7} \mathrm{H}_{14} \mathrm{O}_{7}$ \\
\hline Cpd 7: Benzene,[(tetramethylcyclopropylidene) methyl]- & 12.815 & 6.62 & $\mathrm{C}_{14} \mathrm{H}_{18}$ \\
\hline Cpd 8: 3,6-Dihydrochamazulene & 13.115 & 5.78 & $\mathrm{C}_{14} \mathrm{H}_{18}$ \\
\hline Cpd 9: (4R,4aR)-4,4a-Dimethyl-6-(prop-1-en-2-yl)-1,2,3,4,4a,7-hexahydronaphthalene & 13.357 & 1.71 & $\mathrm{C}_{15} \mathrm{H}_{22}$ \\
\hline Cpd 10: 1,4-Diacetyl-3-acetoxymethyl-2,5-methylene---rhamnitol & 13.548 & 1.04 & $\mathrm{C}_{14} \mathrm{H}_{22} \mathrm{O}_{8}$ \\
\hline Cpd 11: Chamazulene & 14.003 & 9.02 & $\mathrm{C}_{14} \mathrm{H}_{16}$ \\
\hline Cpd 12: (E)-1-(6,10-Dimethylundeca-5,9-dien-2-yl)-4-methylbenzene & 16.788 & 1.46 & $\mathrm{C}_{20} \mathrm{H}_{30}$ \\
\hline Cpd 13: 2-(4a,8-Dimethyl-7-oxo-1,2,3,4,4a,7-hexahydronaphthalen-2-yl)-propionic acid & 17.357 & 11.57 & $\mathrm{C}_{15} \mathrm{H}_{20} \mathrm{O}_{3}$ \\
\hline Cpd 14: Glabellin & 17.428 & 1.64 & $\mathrm{C}_{15} \mathrm{H}_{18} \mathrm{O}_{3}$ \\
\hline Cpd 15: Phytol & 17.677 & 3.86 & $\mathrm{C}_{20} \mathrm{H}_{40} \mathrm{O}$ \\
\hline${ }^{*}$ Cpd 16: 2-Dodecen-1-yl(-)succinic anhydride & 18.358 & 2.04 & $\mathrm{C}_{16} \mathrm{H}_{26} \mathrm{O}_{3}$ \\
\hline Cpd 17: .alpha.-Santonin & 18.596 & 0.92 & $\mathrm{C}_{15} \mathrm{H}_{18} \mathrm{O}_{3}$ \\
\hline Cpd 18: Longifolenaldehyde & 18.658 & 1.91 & $\mathrm{C}_{15} \mathrm{H}_{24} \mathrm{O}$ \\
\hline${ }^{*}$ Cpd 19: 2-Dodecen-1-yl(-)succinic anhydride & 18.785 & 8.80 & $\mathrm{C}_{16} \mathrm{H}_{26} \mathrm{O}_{3}$ \\
\hline Cpd 20: 14-Formol-9-hydroxyarteether & 19.006 & 1.67 & $\mathrm{C}_{17} \mathrm{H}_{26} \mathrm{O}_{7}$ \\
\hline${ }^{*} \mathrm{Cpd}$ 21: Anthracen-1(2H)-one, 3,4-dihydro-8,9,10-trihydroxy- & 19.185 & 1.01 & $\mathrm{C}_{14} \mathrm{H}_{12} \mathrm{O}_{4}$ \\
\hline *Cpd 22: Anthracen-1(2H)-one, 3,4-dihydro-8,9,10-trihydroxy- & 19.514 & 1.04 & $\mathrm{C}_{14} \mathrm{H}_{12} \mathrm{O}_{4}$ \\
\hline Cpd 23: 17-Pentatriacontene & 22.816 & 0.97 & $\mathrm{C}_{35} \mathrm{H}_{70}$ \\
\hline
\end{tabular}

*: these compounds are probably isomers.

The temperature of the sampling unit is $230^{\circ} \mathrm{C} \rightarrow 12^{\circ} \mathrm{C} / \mathrm{s}$ $\rightarrow 275^{\circ} \mathrm{C}$. Thermostat temperature: programmable, $240^{\circ} \mathrm{C}$ (1 minute delay) $\rightarrow 5{ }^{\circ} \mathrm{C} / \mathrm{min} \rightarrow 280^{\circ} \mathrm{C}$ (delay $1 \mathrm{~min}$ ). The total time of examination is $10 \mathrm{~min}$. Temperature of interface GS/MS $-280{ }^{\circ} \mathrm{C}$; ion sources $-230{ }^{\circ} \mathrm{C}$; quadrupole mass analyzer $-150{ }^{\circ} \mathrm{C}$. Type of ionization: EI with an electron energy of $70 \mathrm{eV}$. The range of mass numbers that was scanned: $30-500 \mathrm{~m} / \mathrm{z}$.

\section{Results}

According to the results of the study, 21 compounds were identified ( 2 in the isomeric state) (Table 1).

Regarding chemical analysis, the largest percentage was $\beta$-myrcene (17.22\%), sabinene (14.54\%), 2-(4a, 8-dimethyl7-oxo-1,2,3,4,4a, 7-hexahydronaphthalene-2-yl)-propionic acid (11.57\%), 2-dodecen-1-yl-succinic anhydride (10.84\%) and chamazulene $(9.02 \%)$. Of the total content, terpenes were accounted for $59.06 \%$, aromatic compounds $-11.84 \%$, fatty acid derivatives $-11.57 \%$, organic acid derivatives $10.84 \%$, hydrocarbons $-2.83 \%$, sugars $-2.2 \%$, ester $1.67 \%$.
The chromatogram of Artemisia tschernieviana Bess. tincture identified the following compounds: $\beta$-myrcene $(\mathrm{RT}=4.267), 2-(4 \mathrm{a}, 8$-dimethyl-7-oxo-1,2,3,4,4a, 7-hexahydronaphthalen-2-yl)-propionic acid $(\mathrm{RT}=17.357), 2$-dodecen-1-yl-succinic anhydride $(\mathrm{RT}=18.785)$ (Fig. 1).

\section{Discussion}

According to the literature review, myrcene has antibacterial, anesthetic, and analgesic effects. American scientists have studied the analgesic effect of a mixture of cannabinoids and myrcene and concluded on the prospects of their joint use [14].

Sabinene is characterized by antibacterial action [15].

2-(4a, 8-dimethyl-7-oxo-1,2,3,4,4a, 7-hexahydronaphthalen-2-yl)-propionic acid is a derivative of propionic acid, which is the lowest fatty acid. According to the literature, propionic acid and its derivatives have antibacterial and anti-inflammatory activity [16].

2-dodecen-1-yl-succinic anhydride is used to produce the anhydride-modified form of insulin that can be used in the treatment of diabetes [17]. 


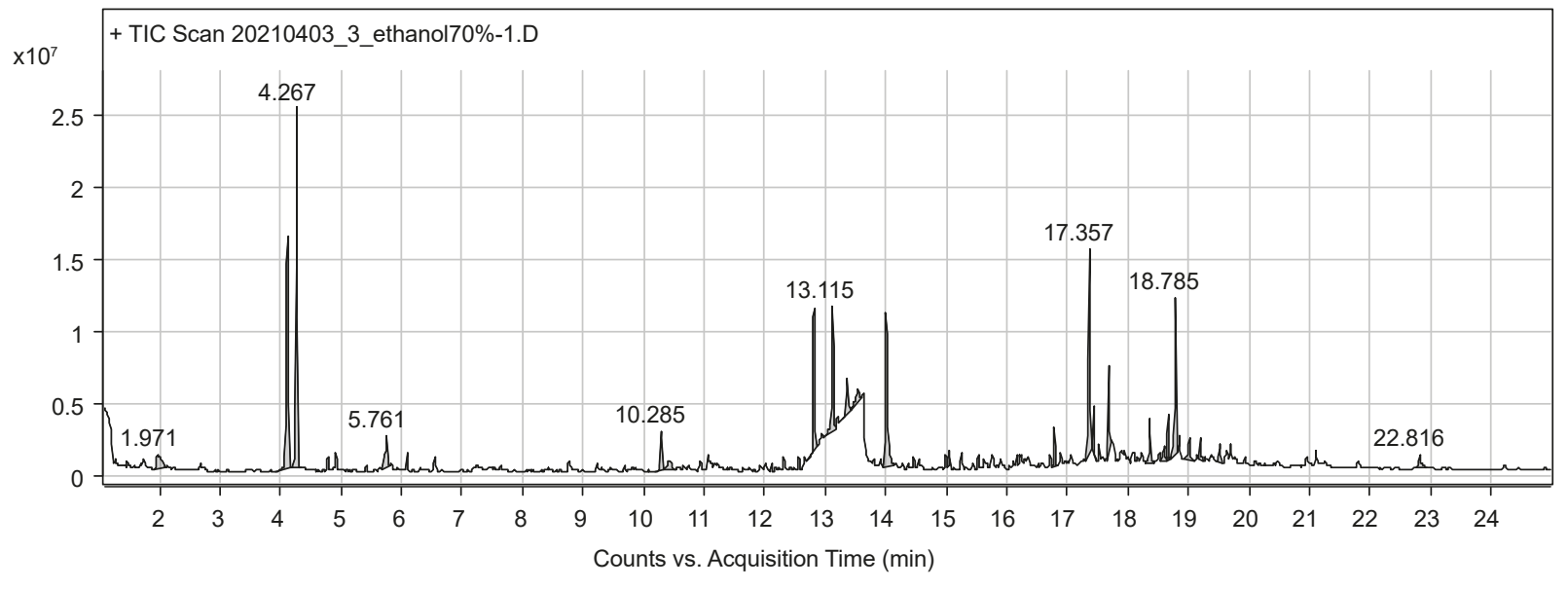

Fig. 1. Chromatogram of Artemisia tschernieviana Bess. grass.

Hamazulene is known as an anti-inflammatory agent [18] and may be included in the treatment of osteoarthritis [19].

In view of all the above, we can conclude that wormwood Chernyaeva grass can be recommended for further research as a source of potential anti-inflammatory and antibacterial agents.

\section{Conclusions}

1. For the first time with the help of GS/MS was established the chemical composition of Artemisia tschernieviana Bess. grass.

2. During the study of raw materials, 21 ( 2 in the isomeric state) biologically active compounds were identified.

3 . The main components were $\beta$-myrcene $(17.22 \%)$, sabinene (14.54\%), 2-(4a, 8-dimethyl-7-oxo-1,2,3,4,4a, 7-hexahydronaphthalen-2-yl)-propionic acid (11.57\%), -dodecen-1-yl-succinic anhydride (10.84\%), and chamazulene $(9.02 \%)$.

4. The obtained results testify to the prospects of further research of Artemisia tschernieviana Bess. grass as a potential source of drugs with antibacterial and anti-inflammatory action.

Prospects for further research. Artemisia tschernieviana Bess. grass can be used as a source of potential drugs with antibacterial and anti-inflammatory effects.

\section{Funding}

The work is part of the joint integrated work of the Department of Pharmacognosy, Pharmacology and Botany of Zaporizhzhia State Medical University.

Conflicts of interest: authors have no conflict of interest to declare. Конфллікт інтересів: відсутній.

\section{Information about authors:}

Panasenko O. I., PhD, DSc, Professor, Head of the Department of Natural Sciences for Foreign Students and Toxicological Chemistry, Zaporizhzhia State Medical University, Ukraine.

ORCID ID: $\underline{0000-0002-6102-3455}$
Mozul V. I., PhD, Associate Professor of the Department of Pharmacognosy, Pharmacology and Botany, Zaporizhzhia State Medical University, Ukraine.

Denysenko O. M., PhD, Associate Professor of the Department of Pharmacognosy, Pharmacology and Botany, Zaporizhzhia State Medical University, Ukraine.

Aksonova I. I., PhD, Teaching Assistant of the Department of Pharmacognosy, Pharmacology and Botany, Zaporizhzhia State Medical University, Ukraine.

ORCID ID: 0000-0002-3534-700X

Holovkin V. V., PhD, Associate Professor of the Department of Pharmacognosy, Pharmacology and Botany, Zaporizhzhia State Medical University, Ukraine.

\section{Відомості про авторів:}

Панасенко О. І., д-р фарм. наук, просресор,

зав. каф. природничих дисциплін для іноземних студентів та токсикологічної хімії, Запорізький державний медичний університет, Україна.

Мозуль В. І., канд. фарм. наук, доцент каф. фрармакогнозії, фармакології та ботаніки, Запорізький державний медичний університет, Україна.

Денисенко О. М., канд. фрарм. наук, доцент каф. фармакогнозії, фармакології та ботаніки, Запорізький державний медичний університет, Україна.

Аксьонова І. І., канд. фрарм. наук, асистент каф. фармакогнозії, фрармакології та ботаніки, Запорізький державний медичний університет, Україна.

Головкін В. В., канд. фарм. наук, доцент каф. фармакогнозії, фармакології та ботаніки, Запорізький державний медичний університет, Україна.

\section{Сведения об авторах:}

Панасенко А. И., д-р фарм. наук, профессор, зав. каф. естественных дисциплин для иностранных студентов и токсикологической химии, Запорожский государственный медицинский университет, Украина. Мозуль В. И., канд. фрарм. наук, доцент каф. фармакогнозии, фармакологии и ботаники, Запорожский государственный медицинский университет, Украина.

Денисенко О. Н., канд. фрарм. наук, доцент каф. фрармакогнозии, фармакологии и ботаники, Запорожский государственный медицинский университет, Украина.

Аксёнова И. И., канд. фрарм. наук, ассистент каф. фрармакогнозии, фармакологии и ботаники, Запорожский государственный медицинский университет, Украина.

Головкин В. В., канд. фрарм. наук, доцент каф. фармакогнозии, фармакологии и ботаники, Запорожский государственный медицинский университет, Украина. 


\section{References}

[1] Genus Artemisia (n.d.). Plantarium. Retrieved from https://www. plantarium.ru/lang/en/page/view/item/42391.html

[2] Rod Polyn' - Artemisia L. (n.d.). Megabook. Megaentsiklopediya Kirilla i Mefodiya. Retrieved from https://megabook.rul article $/ \% \mathrm{~d} 0 \% \mathrm{a} 0 \% \mathrm{~d} 0 \%$ be $\% \mathrm{~d} 0 \% \mathrm{~b} 4 \% 20 \% \mathrm{~d} 0 \% \mathrm{bf} \% \mathrm{~d} 0 \%$ be $\% \mathrm{~d} 0 \% \mathrm{~b}-$ b\%d1 $\% 8 \mathrm{~b} \% \mathrm{~d} 0 \% \mathrm{bd} \% \mathrm{~d} 1 \% 8 \mathrm{c} \% 20 \% \mathrm{e} 2 \% 80 \% 93 \% 20$ Artemisia $\% 20 \mathrm{~L}$.

[3] Artemisia - The Plant List (n.d.). The Plant List. Retrieved from http:// www.theplantlist.org/1.1/browse/A/Compositae/Artemisial

[4] Zanousi, M. B. P., Nekoei, M., \& Mohammadhosseini, M. (2017) Chemical Compositions of the Essential Oils from Stems, Leaves and Fruits of Artemisia tschernieviana and Exploring Quantitative Structure-Retention Relationships (QSRRs) for Prediction of Corresponding Retention Indices. Journal of Essential Oil Bearing Plants, 20(3). 672-687.

[5] Mohammadhosseini, M. (2017). Essential oils extracted using microwave-assisted hydrodistillation from aerial parts of eleven Artemisia species: Chemical compositions and diversities in different geographical regions of Iran. Records of Natural Products, 11(2), 114-129. https://www.acgpubs.org/doc/2018080513061416-RNPEO 1602-010.pdf

[6] Vagabova, F. A., Aliev, A. M., Radjabov, G. K., \& Musaeva, A. M. (2018). Sravnitel'noe izuchenie komponentnogo sostava efirnogo masla Artemisia splendens Willd. i Artemisia tschernieviana Bess. flory Dagestana [Comparative study of the component composition of Artemisia splendens Willd essential oil and Artemisia tschernieviana Bess. flora of Dagestan]. Voprosy biologicheskoi, meditsinskoi i farmatsevticheskoi khimii, (1), 17-24. [in Russian]. https://doi. org/10.29296/25877313-2018-01-04

[7] Nigam, M., Atanassova, M., Mishra, A. P., Pezzani, R., Devkota, H. P., Plygun, S., Salehi, B., Setzer, W. N., \& Sharifi-Rad, J. (2019). Bioactive Compounds and Health Benefits of Artemisia Species. Natural Product Communications, 14(7), 1-17. https://doi. org/10.1177/1934578X19850354

[8] Taleghani, A., Emami, S. A., \& Tayarani-Najaran, Z. (2020). Artemisia: a promising plant for the treatment of cancer. Bioorganic and Medicinal Chemistry, 28(1), 115180. https://doi.org/10.1016/j.bmc.2019.115180

[9] Lang, S. J., Schmiech, M., Hafner, S., Paetz, C., Steinborn, C., Huber, R., Gaafary, M. E., Werner, K., Schmidt, C. Q., Syrovets, T. \& Simmet, T. (2019). Antitumor activity of an Artemisia annua herbal preparation and identification of active ingredients. Phytomedicine, 62, 152962. https://doi.org/10.1016/i.phymed.2019.152962

[10] Shahzadi, I., Abdullah, Mehmood, F., Ali, Z., Ahmed, I., \& Mirza, B. (2020). Chloroplast genome sequences of Artemisia maritima and Artemisia absinthium: Comparative analyses, mutational hotspots in genus Artemisia and phylogeny in family Asteraceae. Genomics, 112(2), 1454-1463. https://doi.org/10.1016/i.ygeno.2019.08.016

[11] Batiha, G. E., Olatunde, A., El-Mleeh, A., Hetta, H. F., Al-Rejaie, S., Alghamdi, S., Zahoor, M., Magdy Beshbishy, A., Murata, T., Zaragoza-Bastida, A., \& Rivero-Perez, N. (2020). Bioactive Compounds, Pharmacological Actions, and Pharmacokinetics of Wormwood (Artemisia absinthium). Antibiotics, 9(6), 353. https://doi.org/10.3390/ antibiotics 9060353

[12] Mohanty, B., Puri, S., \& Kesavan, V. (2018). A Review on Therapeutic Potential of Artemisia nilagirica. Journal of Plant Biochemistry \& Physiology, 6(01). https://doi.org/10.4172/2329-9029.1000205

[13] State Enterprise Ukrainian Scientific Pharmacopoeial Center of Medicines Quality. (2008, February 1). Derzhavna Farmakopeia Ukrainy. Dopovnennia 2 [The State Pharmacopoeia of Ukraine] (1st ed., Suppl. 1). Kharkiv: Naukovo-ekspertnyi farmakopeinyi tsentr. [in Ukrainian].

[14] Jansen, C., Shimoda, L., Kawakami, J. K., Ang, L., Bacani, A. J., Baker, J. D., Badowski, C., Speck, M., Stokes, A. J., Small-Howard, A. L., \& Turner, H. (2019). Myrcene and terpene regulation of TRPV1. Channels, 13(1), 344-366. https://doi.org/10.1080/1933695 0.2019 .1654347

[15] Ngbolua, K. N., Moke, E. L., Baya, J. L., Djoza, R. D., Ashande, C. M., \& Mpiana, P. T. (2017). A mini-review on the pharmacognosy and phytochemistry of a tropical medicinal plant: Annona senegalensis Pers. (Annonaceae). Tropical Plant Research, 4(1), 168-175. https:// doi.org/10.22271/tpr.2017.v4.11.024

[16] Eş, I., Khaneghah, A. M., Hashemi, S. M., \& Koubaa, M. (2017). Current advances in biological production of propionic acid. Biotechnology Letters, 39, 635-645. https://doi.org/10.1007/s10529-017-2293-6

[17] Chinisaz, M., Ebrahim-Habibi, A., Dehpour, A. R., Yaghmaei, P., Parivar, K., \& Moosavi-Movahedi, A. A. (2017). Structure and function of anhydride-modified forms of human insulin: In silico, in vitro and in vivo studies. European journal of pharmaceutical sciences, 96, 342-350. https://doi.org/10.1016/i.ejps.2016.09.030

[18] Misyri, V., Tsekouras, V., lliopoulos, V., Mavrikou, S., Evergetis, E., Moschopoulou, G., Kintzios, S., \& Haroutounian, S. A. (2021). Farm or lab? Chamazulene content of Artemisia arborescens (Vill.) L. essential oil and callus volatile metabolites isolate. Industrial Crops and Products, 160. https://doi.org/10.1016/i.indcrop.2020.113114

[19] Ma, D., He, J., \& He, D. (2020). Chamazulene reverses osteoarthritic inflammation through regulation of matrix metalloproteinases (MMPs) and NF-k $\beta$ pathway in in-vitro and in-vivo models. Bioscience, Biotechnology and Biochemistry, 84(2), 402-410. https://doi.org/10.108 $\underline{0 / 09168451.2019 .1682511}$ 